\title{
INTERAKSI SOSIAL TRANSMIGRAN DESA WERDHI AGUNG DENGAN PENDUDUK ASLI DESA IBOLIAN DI KECAMATAN DUMOGA TENGAH
}

\author{
Claudia Mouren Demakota \\ Welson M. Wangke \\ Jenny Baroleh
}

\begin{abstract}
ABSRACT
This study aims to find out how cooperation, competition, conflict and accommodation between transmigration living in the village of Werdhi Agung with indigenous people in Dumoga Sub-district. This study was conducted from December 2016 to February 2017, starting from preparation to the formulation of the research report. The data used in the form of primary data and secondary data. This research is done by purposive sampling technique. The total respondents in this study were 40 people, who were the head of the family, consisting of 20 members of the transmigrant group from Bali and 20 members of the indigenous Mongondow community representing the local population. Data analysis was done descriptively by using Likert Scale. The results show that: a) The cooperation between transmigrants and indigenous peoples is so harmonious that in their daily life it has reflected a broad assimilation / mixing form arising from the realization that they have common interests, both individually and in groups, they are aware that they have different ethnic cultural backgrounds. This has a positive effect on the social life of transmigration communities and indigenous peoples in coexistence. b) Competition between transmigrants and indigenous people is marked by land ownership / social jealousy competition and competition between village youth but no competition or threat of violence. $c$ ) Conflicts between transmigrants and indigenous peoples only occur in land tenure, and the conflicts are not frequent among rural youth. d) Accommodation or work to end disputes or conflicts between conflicting parties ie between transmigrants and indigenous peoples can be resolved either through the family or with the help of villagers and government officials.
\end{abstract}

Keywords: interaction, social, transmigration, Werdhi Agung Village, Central Dumoga Sub-district

\section{ABSTRAK}

Penelitian ini bertujuan untuk mengetahui bagaimana kerjasama, persaingan, konflik dan akomodasi antara transmigrasi yang tinggal di Desa Werdhi Agung dengan penduduk asli di Kecamatan Dumoga. Penelitian ini dilakukan dari bulan Desember 2016 sampai Februari 2017, dimulai dari persiapan sampai penyusunan laporan. Data yang digunakan berupa data primer dan data sekunder. Penelitian ini dilakukan dengan teknik purposive sampling. Total responden dalam penelitian ini sebanyak 40 orang, yang merupakan Kepala Keluarga, terdiri dari 20 anggota kelompok transmigran asal Bali dan 20 anggota masyarakat adat Mongondow yang mewakili penduduk lokal. Analisis data dilakukan secara deskriptif dengan menggunakan Skala Likert. Hasilnya menunjukkan bahwa: a) Kerja sama yang terjadi antara transmigran dan masyarakat adat terjalin sedemikian harmonis dimana dalam kehidupan sehari-hari mereka telah mencerminkan bentuk asimilasi / pencampuran yang luas timbul karena kesadaran bahwa mereka memiliki kepentingan bersama, baik secara individu maupun secara kelompok walaupun memiliki mereka sadar bahwa mereka memiliki latar belakang etnis budaya yang berbeda. Hal ini memberikan pengaruh positif terhadap kehidupan sosial masyarakat transmigrasi dan masyarakat adat dalam hidup berdampingan secara baik. b) Persaingan terjadi antara transmigran dan penduduk asli ditandai dengan adanya persaingan kepemilikan lahan / kecemburuan sosial tanah dan persaingan antara pemuda desa namun tidak sampai ada persaingan atau ancaman kekerasan. c) Konflik antara transmigran dan masyarakat adat hanya terjadi pada penguasaan lahan / tanah, dan konfliknya tidak sering terjadi dikalangan pemuda desa. d) Akomodasi atau bekerja untuk mengakhiri perselisihan atau konflik antara para pihak yang berkonflik yaitu antara transmigran dengan penduduk asli dapat dipecahkan baik melalui keluarga atau dengan bantuan penduduk desa dan pejabat pemerintah.

Kata kunci: interaksi, sosial, transmigran, Desa Werdhi Agung, Kecamatan Dumoga Tengah 


\section{PENDAHULUAN}

\section{Latar Belakang}

Indonesia merupakan negara kepulauan dengan jumlah penduduk berada pada urutan keempat terbesar didunia setelah Cina, India, dan Amerika serikat. Dari seluruh jumlah penduduk Indonesia, 60\% nya tinggal di pulau Jawa dan Madura yang luasnya hanya $7 \%$ dari luas daerah Indonesia. Dengan jumlah penduduk yang padat dan luas daerahnya kecil ada upaya-upaya pemerintah untuk mengatasi hal tersebut. Salah satu upaya pemerintah adalah melaksanakan transmigrasi. Transmigrasi adalah perpindahan penduduk dari suatu wilayah yang padat penduduknya ke wilayah pulau lain yang penduduknya masih sedikit atau belum ada penduduknya sama sekali. Ada 4 faktor terjadinya transmigrasi persebaran penduduk tidak merata, alasan ekonomi, bencana alam, dan adanya proyek pembangunan dari pemerintah (Sugiharyanto, 2007). Proses perpindahan penduduk atau transmigrasi sudah dikenal sejak lama oleh manusia. Proses perpindahan penduduk terjadi secara menyeluruh di wilayah Indonesia, termasuk di Propinsi Sulawesi Utara. Sulawesi Utara dengan luas wilayah adalah seluas $15.273,56 \mathrm{~km}^{2}$ yang meliputi sebelas kabupaten dan empat kota dan kabupaten Bolaang Mongondow merupakan wilayah yang paling luas dengan luas $3.022,70 \mathrm{~km}^{2}$ atau $19,78 \%$ dari luas wilayah Sulawesi Utara (Badan Pusat Statistik, 2014).

Desa Werdhi Agung yang berada di Kecamatan Dumoga Tengah Kabupaten Bolaang Mongondow yang memiliki luas wilayah 232,3 Ha, dan memiliki jumlah penduduk 1.157 jiwa yang sebagian besar para penduduknya berprofesi sebagai petani dan mayoritas penduduk memeluk agama hindu. Desa Werdhi Agung merupakan salah satu desa transmigrasi yang lokasinya tidak jauh dari pemukiman penduduk asli yaitu desa Ibolian yang juga berada di Kecamatan Dumoga Tengah. Desa Ibolian memiliki luas wilayah 119,62 Ha, dan memiliki jumlah penduduk 2.815 jiwa. Kedatangan masyarakat transmigrasi (pendatang) pada tahun 1963 berasal dari pulau Bali yang merupakan korban bencana alam meletusnya Gunung Agung pada tahun 1963. Desa Werdhi Agung sebagai desa transmigrasi tentunya akan terjadi interaksi sosial. Interaksi sosial adalah proses dimana orang-orang yang berkomunikasi saling pengaruh mempengaruhi dalam pikiran dan tindakan (Lawang, 1989). Interaksi sosial adalah kunci dari semua kehidupan sosial, oleh karena tanpa interaksi sosial, tak akan mungkin ada kehidupan bersama. Interaksi sosial akan terjadi apabila orang perorangan atau kelompok-kelompok manusia bekerja sama, saling berbicara, mengadakan persaingan, pertikaian dan konflik maka dapat dikatakan bahwa interaksi sosial adalah dasar proses sosial. Secara umum bentuk-bentuk interaksi sosial dapat berupa kerjasama, persaingan, konflik dan akomodasi (Soekanto, 1990).

Dalam aplikasinya, masyarakat transmigrasi desa Werdhi Agung berupaya agar dalam kehidupan bermasyarakat yang baru dapat membantu kemajuan desa dan menjaga keharmonisan sesama kelompok masyarakat yang ditunjukan dengan adanya interaksi antara transmigran dengan penduduk asli yaitu dalam hal-hal positif seperti kunjungan perayaan hari besar (keagamaan, hubungan perkawinan), dan gotong royong (pembagian air). Namun di lapangan masih ditemukan permasalahanpermasalahan yaitu terdapat persaingan atau konflik yang terjadi antara transmigran dan penduduk asli seperti penguasaan tanah atau lahan, perdagangan, dan pemuda-pemuda desa, serta kebudayaan yang dalam menyelesaikannya dengan cara akomodasi atau melibatkan pihak ketiga seperti penyelesaian konflik secara kekeluargaan dimana pihak-pihak yang berselisih dipertemukan demi pencapaian tujuan bersama serta penyelesaian konflik oleh pemerintah desa maupun aparat kepolisian. Oleh sebab itu, penulis merasa perlu melakukan penelitian untuk mengetahui bagaimana interaksi sosial antara transmigran Desa Werdhi Agung dengan penduduk asli di Kecamatan Dumoga Tengah.

\section{Rumusan Masalah}

Berdasarkan latar belakang tersebut maka perumusan masalah yaitu bagaimana interaksi sosial antara transmigran Desa Werdhi Agung dengan penduduk asli di Kecamatan Dumoga Tengah.

\section{Tujuan Penelitian}

Penelitian ini bertujuan untuk mengetahui bagaimana kerjasama, persaingan, konflik, serta akomodasi antara transmigran Desa Werdhi Agung dengan penduduk asli di Kecamatan Dumoga Tengah. 


\section{Manfaat Penelitian}

Manfaat dari penelitian ini yaitu sebagai sumber ilmu pengetahuan tentang interaksi sosial transmigran dengan penduduk asli. Diharapkan kepada para pembaca untuk mendapat pengetahuan tentang interaksi sosial transmigran dengan penduduk asli. Penulisan ini juga diharapkan dapat menjadi bahan studi referensi untuk penulis-penulis selanjutnya dan referensi dalam melaksanakan penelitian serupa.

\section{METODOLOGI PENELITIAN}

\section{Waktu Dan Tempat Penelitian}

Penelitian ini dilaksanakan selama tiga bulan yaitu dari bulan Desember tahun 2016 sampai Februari tahun 2017. Tempat penelitian daerah transmigran Desa Werdhi Agung dan penduduk asli di Kecamatan Dumoga Tengah (Desa Ibolian).

\section{Metode Pengumpulan Data}

Data yang digunakan dalam penelitian ini yaitu data primer dan data sekunder. Data primer diperoleh dari wawancara secara langsung dengan responden penduduk transmigran, dan responden penduduk asli berdasarkan daftar pertanyaan (kuisioner) tentang interaksi sosial yang didalamnya kerjasama, persaingan, konflik, serta akomodasi yang telah disiapkan. Data sekunder diperoleh dari instansi terkait seperti Kantor Desa Werdhi Agung dan Kantor Desa Ibolian.

\section{Metode Pengambilan Sampel}

Populasi dalam penelitian ini yaitu penduduk transmigran dan penduduk asli. Metode pengambilan sampel menggunakan metode purposive sampling yaitu pemilihan sampel yang ditentukan secara sengaja sesuai dengan permasalahan yang diteliti. Jumlah responden yang dijadikan sampel sebanyak 40 responden yang terdiri dari 20 responden kepala keluarga transmigran Desa Werdhi Agung dan 20 responden kepala keluarga penduduk asli Desa Ibolian.

\section{Konsep Pengukuran Variabel}

Adapun variabel yang di teliti adalah :

1. Kerja sama (Cooperation)

- Gotong royong : gotong royong yaitu saling membantu bekerjasama dalam bercocok tanam padi sawah dan dalam pembagian sumber air dilakukan secara merata yaitu dengan cara penyaluran melalui saluran irigasi padi sawah.

- Toleransi keagamaan : toleransi keagamaan yaitu saling menghormati terhadap agama lain (Memahami setiap perbedaan, saling kunjung mengunjungi menghargai saat perayaan hari besar).

- Perkawinan transmigran dengan penduduk asli : berbeda etnis atau berlatar belakang budaya untuk di sahkan secara resmi sebagai pasangan suami istri tanpa adanya larangan.

2. Persaingan (Competition)

- Penguasaan tanah/lahan: salah satu kelompok lebih mendominasi kepemilikan tanah/lahan dibanding dengan kelompok yang lain yang berada dalam satu wilayah.

- Persaingan dalam berdagang/pasar : persaingan dalam berdagang yaitu bersaingnya para penjual yang sama-sama berusaha mendapatkan keuntungan. Para penjual biasanya berusaha mengungguli persaingan dengan membedakan harga dan produk.

- Persaingan pemuda-pemuda desa : adanya sikap untuk lebih maju dalam meningkatkan kesejahteraan.

-Persaingan kebudayaan : Menyangkut persaingan kebudayaan yang dianut oleh masing-masing individu yang tinggal dalam satu wilayah.

3. Konflik (Conflict)

- Konflik karena penguasaan tanah : salah satu kelompok lebih mendominasi kepemilikan tanah/lahan dalam satu wilayah.

- Konflik karena persaingan dalam berdagang : keinginan dimana suatu individu ingin mengusai pasar/tempat berjualan untuk meningkatkan keadaaan ekonomi.

-Konflik pemuda-pemuda desa yang terpengaruh minuman keras : konflik yang terjadi akibat minuman beralkohol yang di konsumsi dalam jumlah yang banyak.

- Konflik kebudayaan : kebudayaan yang kental akan menimbulkan konflik antar individu bahkan antar kelompok. Perbedaan kebudayaan memengaruhi pola pemikiran dan tingkah laku perseorangan dalam kelompok kebudayaan yang bersangkutan.

4. Akomodasi (Accomodation)

- Penyelesaian konflik secara kekeluargaan ; menyelesaikan masalah antara ke dua pihak yang saling berselisih secara baikbaik/kekeluargaan tanpa melibatkan pihak dari luar secara damai. 
- Penyelesaian konflik oleh pihak pemerintah desa : menyelesaikan masalah antara ke dua pihak yang saling berselisih dengan di bantu olah pihak pemerintah desa dalam hal ini aparat desa maupun aparat kepolisian dengan syarat-syarat yang telah disepakati bersama.

\section{Metode Analisis Data}

Analisis data yang digunakan dalam penelitian ini adalah secara deskriptif, dianalisis dengan menggunakan skala likert. Data yang dihasilkan dengan menggunakan skala likert dalam analisis ini akan diketahui bentuk-bentuk interaksi sosial yaitu kerjasama, persaingan, konflik, akomodasi antara transmigran dengan penduduk asli. Keempat bentuk-bentuk interaksi sosial kerjasama, persaingan, konflik, akomodasi dianalisis dalam bentuk tabulasi. Untuk mengetahui interaksi sosial akan disusun 13 pertanyaan dengan total responden 40 orang. Setiap jawaban dihubungkan dengan kata-kata yaitu jenjang 1 (tidak setuju), 2 (netral), 3 (setuju). Dengan cara perhitungan skor masing-masing pertanyaan:

Jumlah skor tiap kriterium = Capaian skor $\mathrm{X}$ Jumlah Responden

Untuk:

$\mathrm{S} 3=3 \times 40=120$

$\mathrm{S} 2=2 \times 40=80$

$\mathrm{S} 1=1 \times 40=40$

Jumlah skor ideal untuk setiap pernyataan (skor tertinggi) $=120$

Jumlah skor terendah $=40$

Dengan interpretasi nilai:

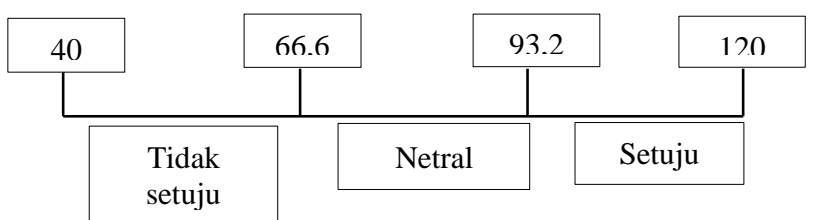

Cara perhitungan skor keseluruhan untuk mengetahui interaksi sosial penduduk transmigran desa Werdhi Agung dengan penduduk asli di Kecamatan Dumoga Tengah. Jumlah skor seluruh kriterium = Capaian jumlah skor $\mathrm{X}$ Jumlah Responden X Jumlah Pertanyaan

Untuk:

$\mathrm{S} 3=3 \times 40 \times 13=1.560$

$\mathrm{S} 2=2 \times 40 \times 13=1.040$

$\mathrm{S} 1=1 \times 40 \times 13=520$

Jumlah skor ideal untuk keseluruhan pertanyaan $=$ 1.560
Jumlah skor terendah $=520$

Analisis data yang digunakan merupakan analisis deskriptif yang diukur dengan skala likert menurut Riduwan (2012) disesuaikan dengan kasus adalah sebagai berikut:

Jumlah Skor Hasil Pengumpulan Data

Tingkat Interaksi Sosial $=\longrightarrow$ X 100\%

Jumlah Skor Hasil Ideal (tertinggi)

Dengan interpretasi nilai:

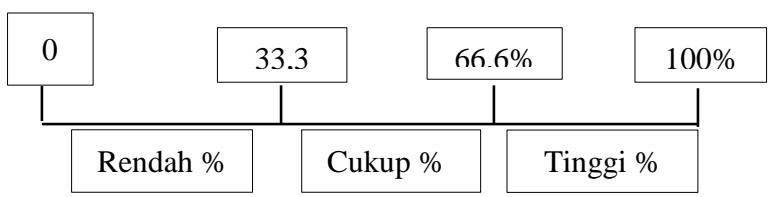

Keterangan kriteria interpretasi skor:

Angka $0-33 \%$

Angka 33,3\% - 66,6\%

Angka 66,6\% - 100\%

$$
\begin{aligned}
& =\text { Rendah } \\
& =\text { Cukup } \\
& =\text { Tinggi }
\end{aligned}
$$

\section{HASIL DAN PEMBAHASAN}

\section{Deskripsi Wilayah Penelitian}

\section{Sejarah Desa}

Desa Werdhi Agung adalah sebuah desa yang berada di wilayah Kecamatan Dumoga Tengah Kabupaten Bolaang Mongondow Propinsi Sulawesi Utara. Masyarakat desa Werdhi Agung berasal dari masyarakat transmigrasi dari Pulau Bali yang merupakan korban bencana alam meletusnya Gunung Agung di Pulau Bali pada Tahun1963.

\section{Kondisi Geografis}

\section{Letak Wilayah Desa Werdhi Agung}

Desa Werdhi Agung merupakan bagian dari Kecamatan Dumoga Tengah, Kabupaten Bolaang Mongondow, Provinsi Sulawesi Utara. Dengan batas wilayah:

Sebelah Utara :Desa Werdhi Agung Utara Sebelah Timur :Desa Werdhi Agung Timur Sebelah Selatan :Desa Werdhi Agung Selatan Sebelah Barat :Desa Ibolian

\section{Letak Wilayah Desa Ibolian}

Desa Ibolian merupakan bagian dari Kecamatan Dumoga Tengah, Kabupaten Bolaang Mongondow, Provinsi Sulawesi Utara. Dengan batas wilayah:
Sebelah Utara Sebelah Timur Sebelah Selatan Sebelah Barat
:Desa Werdhi Agung Timur :Desa Werdhi Agung

:Desa Kinomaligan

:Desa Ibolian 1 


\section{Luas Wilayah Desa Werdhi Agung}

Luas wilayah Desa Werdhi Agung yaitu 232,3 Ha. Desa Werdhi Agung pada umumnya merupakan dataran rendah. Ketinggian dari permukaan laut 387 meter.

\section{Luas Wilayah Desa Ibolian}

Luas wilayah Desa Ibolian yaitu119,62

Ha. Desa ibolian merupakan dataran rendah. Ketinggian dari permukaan laut 387 meter.

\section{Kependudukan}

$\begin{array}{ll}\text { Jumlah Penduduk Desa Werdhi Agung } \\ \text { Jumlah Penduduk } & : 1.157 \\ -\quad \text { Laki-laki } & : 606 \text { Jiwa } \\ \text { - Perempuan } & : 551 \text { Jiwa } \\ \text { Jumlah Kepala Keluarga } & : 492 \mathrm{KK}\end{array}$

Jumlah Penduduk Desa Ibolian

$\begin{array}{cl}\text { Jumlah Penduduk } & : 2.815 \text { Jiwa } \\ -\quad \text { Laki-laki } & : 1.458 \\ \text { - Perempuan } & : 1.357 \\ \text { Jumlah Kepala Keluarga } & : 612 \mathrm{KK}\end{array}$

\section{Karakteristik Responden}

\section{Umur Responden}

Tingkat umur mempengaruhi kemampuan seseorang dalam melakukan aktivitas maupun konsep berpikir. Berikut adalah variasi umur responden dapat dilihat pada Tabel 1.

Tabel 1. Jumlah Responden Berdasarkan Tingkat

\begin{tabular}{|c|c|c|c|}
\hline & Umur & & \\
\hline No & Umur & $\begin{array}{c}\text { Jumlah } \\
\text { Responden }\end{array}$ & Persentase (\%) \\
\hline 1 & $30-37$ & 6 & 15 \\
\hline 2 & $38-45$ & 14 & 35 \\
\hline 3 & $46-53$ & 12 & 30 \\
\hline 4 & $54-61$ & 8 & 20 \\
\hline Jumlah & & 40 & 100 \\
\hline
\end{tabular}

Tabel 1 menunjukan bahwa jumlah responden pada umur 30-37 tahun jumlah 6 responden dengan persentase $15 \%$. Pada umur 3845 tahun jumlah 14 responden dengan persentase sebesar 35\%, pada umur 46-53 tahun jumlah 12 responden dengan persentase $30 \%$, pada umur 5461 tahun jumlah 8 responden dengan persentase 20\%. Ini menunjukan bahwa responden yang paling banyak berada pada umur 38-45 tahun.

\section{Pekerjaan Responden}

Setiap manusia memiliki pekerjaan mereka menurut kemampuan manusia itu sendiri. Dalam penelitian ini pekerjaan responden penduduk transmigran dan penduduk asli dapat dilihat pada Tabel 2.

Tabel 2. Jenis Pekerjaan Responden

\begin{tabular}{cccc}
\hline No & $\begin{array}{c}\text { Jenis } \\
\text { Pekerjaan }\end{array}$ & $\begin{array}{c}\text { Jumlah } \\
\text { Responden }\end{array}$ & $\begin{array}{c}\text { Persentase } \\
(\boldsymbol{\%})\end{array}$ \\
\hline 1 & Petani & 18 & 45 \\
2 & Wraswasta & 9 & 22,5 \\
3 & PNS & 8 & 20 \\
4 & Pedagang & 3 & 7,5 \\
5 & Honorer & 2 & 5 \\
\hline Jumlah & & 40 & 100 \\
\hline
\end{tabular}

Tabel 2 menunjukan bahwa dalam penelitian ini jenis pekerjaan responden yang paling banyak ada pada jenis pekerjaan petani dengan jumlah 18 responden dengan persentase $45 \%$, pada jenis pekerjaan wiraswasta jumlah 9 responden dengan persentase $22,5 \%$, pada jenis pekerjaan PNS jumlah responden 8 dengan persentase $20 \%$, pada jenis pekerjaan pedagang jumlah responden 3 dengan persentase $7,5 \%$, dan paling sedikit pada jenis pekerjaan pekerjaan honorer jumlah 2 responden dengan persentase $5 \%$.

\section{Bentuk-bentuk Interaksi Sosial}

\section{Kerjasama (Cooperation)}

Transmigran dan Penduduk Asli Bergotongroyong Saling Membantu

Kerjasama yaitu bekerja bersama dalam rangka mencapai suatu tujuan bersama. Pernyataan ini ingin melihat apakah responden yang dalam penelitian ini transmigran dan penduduk asli bekerjasama dalam bertani untuk pembagian air dari bendungan/irigasi semua merata. Tabel 3 menjelaskan tentang kerjasama transmigran dan penduduk asli bergotongroyong saling membantu. Hasil penelitian ini menunjukan bahwa 100\% (40 orang) setuju bahwa transmigran dan penduduk asli bergotong royong saling membantu dalam bertani dimana pembagian air dari bendungan/irigasi semua merata. Total skor yang diperoleh dari 40 responden pada indikator pernyataan 1 yaitu sebesar 120. Angka indeks kerjasama pernyataan 1 yaitu $120 / 120 \times 100=100 \%$, sehingga interpretasi nilainya tinggi karena transmigran dan penduduk asli sudah lama saling bekerjasama sehingga pada saat mereka bergotong royong saling membantu dalam 
bertani dimana pembagian air dari bendungan/irigasi semua merata tidak menimbulkan kekecewaan, iri hati, rasa tersinggung ataupun rasa dirugikan.

\section{Toleransi Keagamaan}

Dalam pernyataan ini yang dilihat apakah transmigran dan penduduk asli saling menghormati antar umat beragama misalnya transmigran dan penduduk asli bebas memeluk agama masing-masing dan saling menghormati waktu ibadah masing-masing agama. Tabel 4 menjelaskan tentang toleransi keagamaan. Hasil penelitian ini menunjukan bahwa $100 \%$ (40 orang) setuju bahwa toleransi keagamaan yang terjadi antara transmigran dan penduduk asli saling menghormati, mereka bebas memeluk agama masing-masing dan saling menghormati waktu ibadah masing-masing agama. Total skor yang diperoleh dari 40 responden pada indikator pernyataan 2 adalah sebesar 120. Angka indeks kerjasama mengenai pernyataan 2 yaitu: $120 / 120 \times 100=100 \%$, sehingga interpretasi nilainya tinggi karena transmigran dan penduduk asli saling menghormati antar umat beragama saat perayaan hari besar transmigran dan penduduk asli saling kunjung mengunjungi.

\section{Perkawinan transmigran dan penduduk asli}

Pernyataan ini yang akan dilihat apakah perkawinan antara transmigran dan penduduk asli disatukan tanpa ada larangan dari pihak yang terkait antara transmigran dengan penduduk asli. Tabel 5 menjelaskan tentang perkawinan transmigran dan penduduk asli. Hasil penelitian ini menunjukan bahwa 100\% (40 orang) setuju bahwa perkawinan antara transmigran dengan penduduk asli disatukan tanpa adanya larangan dari pihak manapun bahkan menurut responden bukan hanya perkawinan transmigran Bali yang kawin dengan penduduk asli Mongondow tetapi ada juga orang Minahasa yang kawin dengan orang Mongondow dan disatukan tanpa adanya larangan. Total skor yang diperoleh dari 40 responden pada indikator pernyataan 3 adalah sebesar 120. Angka indeks kerjasama pada pernyataan 3 yaitu: $120 / 120 \times 100=100 \%$, sehingga interpretasi nilainya tinggi karena perkawinan transmigran dengan penduduk asli disatukan tanpa adanya larangan bukan hanya perkawinan transmigran Bali yang kawin dengan penduduk asli Mongondow tetapi ada juga orang Minahasa yang kawin dengan orang Mongondow.

\section{Persaingan (Competition)}

\section{Penguasaan Tanah/lahan}

Dalam pernyataan ini yang dilihat apakah transmigran dan penduduk asli bersaing dalam penguasaan tanah/lahan. Tabel 6 menjelaskan tentang apakah ada atau tidaknya persaingan antara transmigran dan penduduk asli dalam penguasaan tanah/lahan. Hasil penelitian ini menunjukan bahwa 100\% (40 orang) setuju transmigran dan penduduk asli bersaing dalam penguasaan tanah/lahan dimana transmigran lebih mendominasi kepemilikan tanah/lahan dibanding dengan penduduk asli. Total skor yang diperoleh dari 40 responden pada indikator pernyataan 4 adalah sebesar 120. Angka indeks persaingan mengenai pernyataan 4 yaitu: 120/120x $100 \%=$ $100 \%$, sehingga interpretasi nilainya tinggi berdasarkan hasil wawancara dengan responden transmigran maupun responden penduduk asli bahwa keberhasilan yang didapat oleh transmigran memang tidak mudah semua itu di peroleh lewat perjuangan berat. Transmigran dikenal begitu ulet dan tekun dalam bertani, transmigran sekarang sudah cukup berhasil. Sehingga transmigran lebih mendominasi penguasaan tanah/lahan hal ini disebabkan karena gaya hidup penduduk asli contohnya pada saat penduduk asli akan mengadakan acara mereka membutukan dana, sehingga mereka seringkali menjual tanah/lahan kepada penduduk transmigran.

\section{Persaingan Dalam Berdagang}

Pernyataan ini untuk melihat apakah persaingan dalam berdagang ada pada transmigran dan penduduk asli salah satunya ingin menguasai pasar. Tabel 7 menjelaskan tentang apakah ada atau tidaknya persaingan dalam berdagang antara transmigran dan penduduk asli salah satunya ingin menguasai pasar. Hasil penelitian ini menunjukan bahwa 75\% (30 orang yang terdiri dari 14 responden penduduk asli dan 16 responden penduduk transmigran) netral mereka tidak memilih setuju maupun tidak setuju mereka masih ragu bahwa transmigran dan penduduk asli bersaing dalam usaha dagang salah satunya ingin menguasai pasar karena yang berdagang dipasar bukan hanya transmigran dan penduduk asli saja melainkan ada juga orang luar yang datang berdagang seperti orang Minahasa, Bugis, dan Jawa. Sedangkan 25\% (10 orang yang terdiri dari 6 responden penduuduk asli dan 4 responden 
penduduk transmigran) tidak setuju karena mereka merasa tidak ada persaingan dalam usaha dagang salah satunya ingin menguasai pasar antara transmigran dan penduduk asli. Total skor yang diperoleh dari 40 responden pada indikator pernyataan 5 yaitu sebesar 70. Angka indeks persaingan mengenai pernyataan 5 yaitu: $70 / 120 \times 100 \%=58,33 \%$, sehingga interpretasi nilainya cukup ada persaingan dalam berdagang hasil pertanian.Berdasarkan hasil penelitian ini penduduk asli dan penduduk transmigran bertemu di pasar dengan menjual hasil pertanian (hasil dagang) berupa beras, buah-buahan (salak), serta hasil ternak dan menurut responden tidak ada persaingan dalam menguasai pasar karena yang berdagang dipasar bukan hanya transmigran dan penduduk asli saja melainkan ada juga orang luar yang datang berdagang seperti orang Minahasa, Bugis, dan Jawa.

Tabel 3. Transmigran dan Penduduk Asli Bergotong-royong Saling Membantu

\begin{tabular}{ccccccc}
$\begin{array}{c}\text { Alternatif } \\
\text { Jawaban }\end{array}$ & $\begin{array}{c}\text { Alternatif } \\
\text { Skor }\end{array}$ & Penduduk Asli & $\begin{array}{c}\text { Jumlah Responden } \\
\text { Transmigran }\end{array}$ & Jumlah & $\begin{array}{c}\text { Persentase } \\
\text { Responden }(\%)\end{array}$ & $\begin{array}{c}\text { Total } \\
\text { Skor }\end{array}$ \\
\hline 1 & 3 & 20 & 20 & 40 & 100 & 120 \\
2 & 2 & - & - & - & - & - \\
3 & 1 & - & - & - & - & - \\
\hline Total & & 20 & 20 & 40 & 100 & 120 \\
\hline
\end{tabular}

Tabel 4. Toleransi Keagamaan

\begin{tabular}{ccccccc}
\hline $\begin{array}{c}\text { Alternatif } \\
\text { Jawaban }\end{array}$ & $\begin{array}{c}\text { Alterna } \\
\text { tif Skor }\end{array}$ & Penduduk Asli & $\begin{array}{c}\text { Jumlah Responden } \\
\text { Transmigran }\end{array}$ & Jumlah & $\begin{array}{c}\text { Persentase } \\
\text { Responden (\%) }\end{array}$ & Total Skor \\
\hline 1 & 3 & 20 & 20 & 40 & 100 & 120 \\
2 & 2 & - & - & - & - & - \\
3 & 1 & - & 20 & 40 & 100 & 120 \\
\hline Total & & 20 & & & & \\
\hline
\end{tabular}

Tabel 5. Perkawinan Transmigran dan Penduduk Asli

\begin{tabular}{ccccccc}
\hline $\begin{array}{c}\text { Alternatif } \\
\text { Jawaban }\end{array}$ & $\begin{array}{c}\text { Alternatif } \\
\text { Skor }\end{array}$ & Penduduk Asli & Transmigran & Jumlah & $\begin{array}{c}\text { Persentase } \\
\text { Responden (\%) }\end{array}$ & Total Skor \\
\hline 1 & 3 & 20 & 20 & 40 & 100 & 120 \\
2 & 2 & - & - & - & - & - \\
3 & 1 & - & 20 & 40 & 100 & 120 \\
\hline Total & & 20 & & & & - \\
\hline
\end{tabular}

Tabel 6. Persaingan Dalam Penguasaan Tanah/lahan

\begin{tabular}{|c|c|c|c|c|c|c|}
\hline \multirow{2}{*}{$\begin{array}{c}\text { Alternatif } \\
\text { Jawaban }\end{array}$} & \multirow{2}{*}{$\begin{array}{l}\text { Alternatif } \\
\text { Skor }\end{array}$} & \multicolumn{3}{|c|}{ Jumlah Responden } & \multirow{2}{*}{$\begin{array}{c}\text { Persentase } \\
\text { Responden }(\%)\end{array}$} & \multirow[t]{2}{*}{ Total Skor } \\
\hline & & Penduduk Asli & Transmigran & Jumlah & & \\
\hline 1 & 3 & 20 & 20 & 40 & 100 & 120 \\
\hline 2 & 2 & - & - & - & - & - \\
\hline 3 & 1 & - & - & - & - & - \\
\hline Total & & 20 & 20 & 40 & 100 & 120 \\
\hline
\end{tabular}

Tabel 7. Persaingan Dalam Berdagang

\begin{tabular}{ccccccc}
\hline $\begin{array}{c}\text { Alternatif } \\
\text { Jawaban }\end{array}$ & $\begin{array}{c}\text { Alternatif } \\
\text { Skor }\end{array}$ & Penduduk Asli & $\begin{array}{c}\text { Jumlah Responden } \\
\text { Transmigran }\end{array}$ & Jumlah & $\begin{array}{c}\text { Persentase } \\
\text { Responden }(\%)\end{array}$ & Total Skor \\
\hline 1 & 3 & - & - & - & - & - \\
2 & 2 & 14 & 16 & 30 & 75 & 60 \\
3 & 1 & 6 & 4 & 10 & 25 & 10 \\
\hline Total & & 20 & 20 & 40 & 100 & 70 \\
\hline
\end{tabular}




\section{Persaingan Pemuda-pemuda Desa}

Persaingan pemuda-pemuda transmigran dengan pemuda-pemuda penduduk asli ada perbedaan karena pemuda-pemuda transmigran rajin bekerja sehingga tahap kesejahteraannya lebih maju dari pemuda-pemuda penduduk asli. Tabel 8 menjelaskan tentang persaingan pemudapemuda desa. Hasil penelitian menunjukan bahwa $80 \%$ (32 orang yang terdiri dari 17 responden penduduk asli dan 15 responden penduduk transmigran) setuju pemuda-pemuda transmigran dan pemuda-pemuda penduduk asli ada persaingan karena pemuda-pemuda transmigran rajin bekerja sehingga tahap kesejahteraannya lebih maju dari pemuda penduduk asli. Sedangkan $20 \%$ (8 orang yang terdiri dari 3 responden penduduk asli dan 5 responden penduduk transmigran) netral mereka tidak menjawab setuju maupun tidak setuju hal ini karena responden masih ragu-ragu untuk menjawab ada tidaknya persaingan antara pemuda-pemuda transmigran dan pemuda-pemuda penduduk asli. Total skor yang diperoleh dari 40 responden pada indikator pernyataan 6 yaitu sebesar 112. Angka indeks persaingan mengenai pernyataan 6 yaitu $112 / 120 \times 100=93,33 \%$, sehingga interpretasi nilanya tinggi karena responden penduduk asli paling banyak menjawab setuju karena mereka merasa adanya persaingan hal ini di karenakan pemuda transmigran lebih rajin bekerja dari pemuda penduduk asli.

\section{Persaingan Kebudayaan}

Dengan adanya budaya, kita dapat saling mengenal siapa diri kita meskipun corak dan bentuknya berbeda-beda, setiap masyarakat pasti memiliki kebudayaan masing-masing serta merupakan salah satu aspek yang memiliki nilai dan makna dalam hidup bermasyarakat. Tabel 9 berikut menjelaskan tentang apakah ada atau tidaknya persaingan kebudayaan transmigran dan penduduk asli. Hasil penelitian ini menunjukan bahwa $45 \%$ (18 orang terdiri dari 7 responden penduduk asli dan 11 responden penduduk transmigran) setuju bahwa transmigran dan penduduk asli bersaing dalam kebudayaan karena transmigran dan penduduk asli masingmasing kental dengan ajaran agama dan adat istiadat mereka, sedangkan 55\% (22 orang yang terdiri dari 13 responden penduduk asli dan 9 responden penduduk transmigran) tidak setuju transmigran dan penduduk asli bersaing dalam kebudayaan karena responden beranggapan mereka saling menghormati masing-masing kebudayaan yang ada. Total skor yang diperoleh dari 40 responden pada indikator pernyataan 7 yaitu sebesar 76. Angka indeks persaingan mengenai pernyataan 7 yaitu: $76 / 120 \times 100=63,33 \%$, sehingga interpretasi nilainya cukup ada persaingan transmigran dan penduduk asli kental dengan ajaran agama dan adat istiadat. Berdasarkan wawancara dengan responden transmigran dan responden penduduk asli, dimana kebudayaan transmigran dikenal dengan upacara ngaben (pembakaran mayat), hariraya nyepi, kuningan, dan galungansedangkan kebudayaan penduduk asli Mongondow upacara perkawinan serta upacara kematian.

\section{Konflik (Conflict)}

\section{Konflik Karena Penguasaan Tanah}

Dalam pernyataan ini yang dilihat apakah transmigran dan penduduk asli terjadi konflik dalam penguasaan tanah/lahan. Tabel 10 menjelaskan tentang apakah ada atau tidak terjadi konflik antara penduduk transmigran dan penduduk asli dalam penguasaan tanah/lahan. Hasil penelitian ini menunjukan bahwa 57,5\% (23 orang yang terdiri dari 12 responden penduduk asli dan 11 responden penduduk transmigran) setuju transmigran dan penduduk asli terjadi konflik dalam penguasaan tanah/lahan dimana transmigran lebih mendominasi kepemilikan tanah/lahan dibanding dengan penduduk asli. $7,5 \%$ (3 orang yang terdiri dari 2 responden penduduk asli dan 1 responden penduduk transmigran) netral mereka masih ragu untuk menjawab setuju atau tidak setuju bahwa ada terjadi konflik dalam penguasaan tanah/lahan, $35 \%$ (14 orang yang terdiri dari 6 responden penduduk asli dan 8 responden penduduk transmigran) tidak setuju terjadi konflik dalam penguasaan tanah/lahan karena responden yang mengatakan tidak setuju tidak ada masalah dalam penguasaan tanah/lahan. Total skor yang diperoleh dari 40 responden pada indikator pernyataan 8 adalah sebesar 89. Angka indeks persaingan mengenai pernyataan 8 yaitu: $89 / 120 \times 100 \%=74,16 \%$, sehingga interpretasi nilainya tinggi karena dari hasil wawancara dengan responden bahwa sampai saat ini masih terjadi konflik dalam penguasaan tanah/lahan 


\section{Konflik Dalam Berdagang}

Dalam pernyataan ini untuk melihat apakah konflik dalam berdagang antara transmigran dan penduduk asli salah satunya ingin menguasai pasar. Tabel 11 menjelaskan tentang apakah ada atau tidaknya konflik dalam berdagang antara transmigran dan penduduk asli salah satunya ingin menguasai pasar. Hasil penelitian ini menunjukan bahwa $100 \%$ (40 orang) tidak setuju antara penduduk transmigran dengan penduduk asli tidak terjadi konflik dalam berdagang, mereka sama-sama berusaha untuk memenuhi kebutuhan hidup tanpa merugikan satu sama lain. Total skor yang diperoleh dari 40 responden pada indikator pernyataan 9 adalah sebesar 40. Angka indeks konflik mengenai pernyataan 9 yaitu: 40/120x100\% $=33,33 \%$, sehingga interpretasi nilainya rendah berdasarkan hasil wawancara dengan responden bahwa tidak terjadi konflik dalam berdagang karena yang berdagang dipasar bukan hanya transmigran dan penduduk asli saja melainkan ada juga orang luar yang datang berdagang seperti orang Minahasa, Bugis, dan Jawa mereka sama-sama menjual hasil pertanian (hasil dagang) berupa beras, buah-buahan (salak), dan hasil ternak tanpa merugikan satu sama lain.

\section{Konflik Pemuda-pemuda Desa Yang Terpengaruh Minuman Keras}

Konflik pemuda-pemuda transmigran dengan pemuda-pemuda penduduk asli konflik yang dipengaruhi atau disebabkan karena minuman keras yang berlebihan sehingga tidak dapat mengontrol diri dalam berbicara dimana pemuda transmigran dengan kemajuan yang dimiliki contohnya kendaraan bermotor yang sudah lebih canggih dibanding dengan kendaraan bermotor pemuda penduduk asli. Tabel 12 menjelaskan tentang konflik pemuda-pemuda desa. Hasil penelitian ini menunjukan bahwa $10 \%$ (4 orang terdiri dari 2 responden penduduk asli dan 2 responden penduduk transmigran) setuju pemuda-pemuda transmigran dan pemudapemuda penduduk asli terjadi konflik yang disebabkan oleh minuman keras. 90\% (36 orang terdiri dari 18 responden penduduk asli dan 18 responden penduduk transmigran) tidak setuju terjadi konflik yang disebabkan oleh minuman keras. Total skor yang diperoleh dari 40 responden pada indikator pernyataan 10 yaitu sebesar 48. Angka indeks konflik mengenai pernyataan 10 yaitu $48 / 120 \times 100=40 \%$, sehingga interpretasi nilanya cukup karena menurut responden penduduk asli maupun responden penduduk transmigran konflik karena minuman keras sekarang tidak sering terjadi antara pemudapemuda penduduk transmigran dan pemudapemuda penduduk asli.

Tabel 8. Persaingan Pemuda-pemuda Desa

\begin{tabular}{|c|c|c|c|c|c|c|}
\hline \multirow{2}{*}{$\begin{array}{c}\text { Alternatif } \\
\text { Jawaban }\end{array}$} & \multirow{2}{*}{$\begin{array}{c}\text { Alternatif } \\
\text { Skor }\end{array}$} & \multicolumn{3}{|c|}{ Jumlah Responden } & \multirow{2}{*}{$\begin{array}{c}\text { Persentase } \\
\text { Responden } \\
(\%)\end{array}$} & \multirow[t]{2}{*}{ Total Skor } \\
\hline & & Penduduk Asli & Transmigran & Jumlah & & \\
\hline 1 & 3 & 17 & 15 & 32 & 80 & 96 \\
\hline 2 & 2 & 3 & 5 & 8 & 20 & 16 \\
\hline 3 & 1 & - & - & - & - & - \\
\hline Total & & 20 & 20 & 40 & 100 & 112 \\
\hline
\end{tabular}

Tabel 9. Persaingan Kebudayaan

\begin{tabular}{ccccccc}
\hline $\begin{array}{c}\text { Alternatif } \\
\text { Jawaban }\end{array}$ & $\begin{array}{c}\text { Alternatif } \\
\text { Skor }\end{array}$ & Penduduk Asli & $\begin{array}{c}\text { Jumlah Responden } \\
\text { Transmigran }\end{array}$ & Jumlah & $\begin{array}{c}\text { Persentase } \\
\text { Responden } \\
(\%)\end{array}$ & Total Skor \\
\hline 1 & 3 & 7 & 11 & 18 & 45 & 54 \\
2 & 2 & - & - & - & - & - \\
3 & 1 & 13 & 9 & 22 & 55 & 22 \\
\hline Total & & 20 & 20 & 40 & 100 & 76 \\
\hline
\end{tabular}


Tabel 11. Konflik Dalam Berdagang

\begin{tabular}{ccccccc}
\hline $\begin{array}{c}\text { Alternatif } \\
\text { Jawaban }\end{array}$ & $\begin{array}{c}\text { Alternatif } \\
\text { Skor }\end{array}$ & Penduduk Asli & $\begin{array}{c}\text { Jumlah Responden } \\
\text { Transmigran }\end{array}$ & Jumlah & $\begin{array}{c}\text { Persentase } \\
\text { Responden (\%) }\end{array}$ & Total Skor \\
\hline 1 & 3 & - & - & - & - & - \\
2 & 2 & - & - & - & - & 40 \\
3 & 1 & 20 & 20 & 40 & 100 & 40 \\
\hline Total & & 20 & 20 & 40 & 100 & 40 \\
\hline
\end{tabular}

Tabel 12. Konflik Pemuda-pemuda Desa Yang Terpengaruh Minuman Keras

\begin{tabular}{ccccccc}
$\begin{array}{c}\text { Alternatif } \\
\text { Jawaban }\end{array}$ & $\begin{array}{c}\text { Alternatif } \\
\text { Skor }\end{array}$ & Penduduk Asli & $\begin{array}{c}\text { Jumlah Responden } \\
\text { Transmigran }\end{array}$ & Jumlah & $\begin{array}{c}\text { Persentase } \\
\text { Responden } \\
(\%)\end{array}$ & Total Skor \\
\hline 1 & 3 & 2 & 2 & 4 & 10 & 12 \\
2 & 2 & - & - & - & - & - \\
3 & 1 & 18 & 18 & 36 & 90 & 36 \\
\hline Total & & 20 & 20 & 40 & 100 & 48 \\
\hline
\end{tabular}

\section{Konflik Kebudayaan}

Tabel 13 menjelaskan tentang apakah ada atau tidaknya konflik kebudayaan transmigran dan penduduk asli. Hasil penelitian ini menunjukan bahwa $100 \%$ (40 orang) tidak setuju terjadi konflik kebudayaan antara transmigran dan penduduk asli karena mereka saling menghormati dan menghargai masing-masing kebudayaan yang ada. Total skor yang diperoleh dari 40 responden pada indikator pernyataan 11 yaitu sebesar 40. Angka indeks persaingan mengenai pernyataan 11 yaitu: $40 / 120 \times 100=33,33 \%$, sehingga interpretasi nilainya rendah karena sampai sekarang tidak pernah terjadi konflik dalam kebudayaan antara transmigran dan penduduk asli.

\section{Akomodasi (Accommodation)}

\section{Penyelesaian Konflik Secara Kekeluargaan}

Pernyataan ini transmigran dan penduduk asli menyelesaikan konflik secara kekeluargaan misalnya saling mempertemukan/menyesuaikan keinginan pihak-pihak yang berselisih demi pencapaian tujuan (rujuk). Tabel 14 menjelaskan tentang penyelesaian konflik secara kekeluargaan. Hasil penelitian ini menunjukan bahwa 100\% (40 orang) setuju bahwa transmigran dan penduduk asli dapat menyelesaikan konflik secara kekeluargaan. Total skor yang diperoleh dari 40 responden pada indikator pernyataan 12 yaitu sebesar 120. Angka indeks akomodasi pernyataan 12 yaitu 120/120x100 $=100 \%$, sehingga interpretasi nilainya tinggi karena transmigran dan penduduk asli dapat menyelesaikan konflik dengan cara kekeluargaan dimana pihakpihak yang berselisih dipertemukan demi pencapaian tujuan bersama (rujuk).

\section{Penyelesaian Konflik Oleh Pihak Pemerintah Desa dan Aparat Kepolisian}

Dalam pernyataan ini yang dilihat apakah transmigran dan penduduk asli dapat menyelesaikan konfllik oleh pemerintah desa dan aparat kepolisian. Tabel 15 berikut menjelaskan tentang penyelesaian konflik oleh pihak pemerintah desa. Hasil penelitian ini menunjukan bahwa $100 \%$ (40 orang) setuju bahwa penyelesain konflik yang terjadi dapat diselesaikan oleh pihak pemerintah desa dan aparat kepolisian. Total skor yang diperoleh dari 40 responden pada indikator pernyataan 13 yaitu sebesar 120. Angka indeks akomodasi pernyataan 13 yaitu $120 / 120 \times 100=100 \%$, sehingga interpretasi nilainya tinggi karena transmigran dan penduduk asli dapat menyelesaikan konflik oleh pihak pemerintah desa dan aparat kepolisian.

Tabel 13. Konflik Kebudayaan

\begin{tabular}{ccccccc}
\hline $\begin{array}{c}\text { Alternatif } \\
\text { Jawaban }\end{array}$ & $\begin{array}{c}\text { Alternatif } \\
\text { kor }\end{array}$ & Penduduk Asli & $\begin{array}{c}\text { Jumlah Responden } \\
\text { Transmigran }\end{array}$ & Jumlah & $\begin{array}{c}\text { Persentase } \\
\text { Responden }(\%)\end{array}$ & $\begin{array}{c}\text { Total } \\
\text { Skor }\end{array}$ \\
\hline 1 & 3 & - & - & - & - & - \\
2 & 2 & - & - & - & - & - \\
3 & 1 & 20 & 20 & 40 & 100 & 40 \\
\hline Total & & 20 & 20 & 40 & 100 & 40 \\
\hline
\end{tabular}


Tabel 14. Penyelesaian Konflik Secara Kekeluargaan

\begin{tabular}{|c|c|c|c|c|c|c|}
\hline \multirow{2}{*}{$\begin{array}{c}\text { Alternatif } \\
\text { Jawaban }\end{array}$} & \multirow{2}{*}{$\begin{array}{c}\text { Alternatif } \\
\text { Skor }\end{array}$} & \multicolumn{3}{|c|}{ Jumlah Responden } & \multirow{2}{*}{$\begin{array}{c}\text { Persentase } \\
\text { Responden }(\%)\end{array}$} & \multirow{2}{*}{$\begin{array}{l}\text { Total } \\
\text { Skor }\end{array}$} \\
\hline & & Penduduk Asli & Transmigran & Jumlah & & \\
\hline 1 & 3 & 20 & 20 & 40 & 100 & 120 \\
\hline 2 & 2 & - & - & - & - & - \\
\hline 3 & 1 & - & - & - & - & - \\
\hline Total & & 20 & 20 & 40 & 100 & 120 \\
\hline
\end{tabular}

Tabel 15. Penyelesaian Konflik Oleh Pihak Pemerintah Desa dan Aparat Kepolisian

\begin{tabular}{|c|c|c|c|c|c|c|}
\hline \multirow{2}{*}{$\begin{array}{l}\text { Alternatif } \\
\text { Jawaban }\end{array}$} & \multirow{2}{*}{$\begin{array}{l}\text { Alternatif } \\
\text { Skor }\end{array}$} & \multicolumn{3}{|c|}{ Jumlah Responden } & \multirow{2}{*}{$\begin{array}{c}\text { Persentase } \\
\text { Responden }(\%)\end{array}$} & \multirow{2}{*}{$\begin{array}{l}\text { Total } \\
\text { Skor }\end{array}$} \\
\hline & & Penduduk Asli & Transmigran & Jumlah & & \\
\hline 1 & 3 & 20 & 20 & 40 & 100 & 120 \\
\hline 2 & 2 & - & - & - & - & - \\
\hline 3 & 1 & - & - & - & - & - \\
\hline Total & & 20 & 20 & 40 & 100 & 120 \\
\hline
\end{tabular}

Rekapitulasi Indeks Interaksi Sosial Transmigran Desa Werdhi Agung Dengan Penduduk Asli di Kecamatan Dumoga Tengah Tiap Indikator dan Interpretasi Hasil

Penelitian ini untuk mengukur interaksi sosial transmigran dengan penduduk asli yang diterapkan mengambil 13 indikator sebagai tolak ukur dalam penelitian ini, dimana masingmasing terbagi dalam 4 (empat) bagian yaitu Kerjasama (Cooperation), Persaingan (Competition), Konflik (Conflict), Akomodasi (Accommodation).

Tabel 16 menunjukan bahwa dari 13 indikator, indikator 1 sampai indikator 3, mendapatkan skor pada indeks yang tergolong tinggi (66,6-100\%) kerjasama terjalin harmonis melalui hubungan kerjasama gotong royong saling membantu bercocok tanam dalam bertani dimana pembagian air dari bendungan/irigasi semua merata, toleransi keagaamaan, dan hubungan perkawinan. Indikator 4 mendapatkan skor pada indeks yang tergolong tinggi (66,6-100\%) persaingan tanah/lahan dimana transmigran lebih mendominasi kepemilikan tanah/lahan dibanding dengan penduduk asli. Indikator 6 mendapatkan skor pada indeks yang tergolong tinggi (66,6$100 \%)$ persaingan pemuda-pemuda desa. Indikator 8 mendapatkan skor pada indeks yang tergolong tinggi (66,6-100\%) konflik penguasaan tanah/lahan. serta indikator 12 sampai indikator 13 mendapatkan skor pada indeks yang tergolong tinggi (66,6-100\%) penyelesaian konflik yang baik secara kekeluargaan dimana pihak-pihak yang berselisih dipertemukan demi pencapaian tujuan bersama serta penyelesaian konflik oleh pemerintah desa maupun aparat kepolisian. Indikator 5 persaingan dalam berdagang mendapatkan indeks tergolong cukup transmigran dan penduduk asli bersaing hanya dalam berdagang hasil pertanian berupa (hasil dagang) berupa beras, buah-buahan (salak), serta hasil ternak dan tidak ada persaingan dalam menguasai pasar karena yang berdagang dipasar bukan hanya transmigran dan penduduk asli saja melainkan ada juga orang luar yang datang berdagang seperti orang Minahasa, Bugis, dan Jawa. indikator 7 persaingan kebudayaan mendapatkan skor tergolong cukup ada persaingan transmigran dan penduduk asli kental dengan ajaran agama dan adat istiadat. Serta indikator 10 konflik pemuda-pemuda desa mendapatkan skor pada indeks yang tergolong cukup karena konflik minuman keras sekarang tidak sering terjadi antara pemuda-pemuda penduduk transmigran dan pemuda-pemuda penduduk asli $(33,3-66,6 \%)$. Indikator 9 serta indikator 11 mendapatkan skor pada indeks yang tergolong rendah (0$33,3 \%)$.

Untuk mengetahui tingkat interaksi sosial transmigran desa Werdhi Agung dengan penduduk asli di Kecamatan Dumoga Tengah maka perlu dihitung jumlah keseluruhan skor pada setiap kriterium, dimana sesuai hasil penelitian ini skor mencapai 1.195. Pada penelitian ini, jumlah skor ideal skor tertinggi 1.560 (tinggi) dan 
jumlah skor terendah yaitu 520 (rendah). Berdasarkan data yang dihimpun dari sebanyak 13 indikator pernyataan yang diajukan kepada 40 orang responden, maka diperoleh total skor 1.195. Secara persentase, angka indeks tingkat interaksi sosial transmigran desa Werdhi Agung dengan Penduduk asli di Kecamatan Dumoga Tengah terletak pada:

Jumlah Skor Hasil Pengumpulan Data

Tingkat Interaksi Sosial $=\longrightarrow$ X 100\%

$$
\begin{gathered}
\text { Jumlah Skor Ideal (tertinggi) } \\
=\frac{1195}{1560} x 100 \%=76,60 \%
\end{gathered}
$$

Berdasarkan hasil analisis menggunakan

skala likert, maka dapat diketahui bahwa

\begin{tabular}{|c|c|c|c|c|}
\hline No & Pernyataan & Total Skor & $\begin{array}{c}\text { Indeks Interaksi Sosial } \\
(\%)\end{array}$ & Interpretasi \\
\hline 1. & $\begin{array}{l}\text { Transmigran dan Penduduk Asli Bergotong- } \\
\text { royong Saling Membantu }\end{array}$ & 120 & 100 & Tinggi \\
\hline 2. & Toleransi Keagamaan & 120 & 100 & Tinggi \\
\hline 3. & $\begin{array}{c}\text { Perkawinan Penduduk Transmigran dengan } \\
\text { Penduduk Asli }\end{array}$ & 120 & 100 & Tinggi \\
\hline 4. & Persaingan penguasaan Tanah/Lahan & 120 & 100 & Tinggi \\
\hline 5. & Persaingan Dalam Berdagang & 70 & 58,33 & Cukup \\
\hline 6. & Persaingan Pemuda-pemuda Desa & 112 & 93,33 & Tinggi \\
\hline 7. & Persaingan Kebudayaan & 76 & 63,33 & Cukup \\
\hline 8. & Konflik Penguasaan Tanah/Lahan & 89 & 74,16 & Tinggi \\
\hline 9. & Konflik Dalam Berdagang & 40 & 33,33 & Rendah \\
\hline 10. & Konflik Pemuda-pemuda Desa & 48 & 40 & Cukup \\
\hline 11. & Konflik Kebudayaan & 40 & 33,33 & Rendah \\
\hline 12. & Penyelesaian Konflik Secara Kekeluargaan & 120 & 100 & Tinggi \\
\hline 13. & $\begin{array}{c}\text { Penyelesaian Konflik Oleh Pihak } \\
\text { Pemerintah Desa dan Aparat Kepolisian. }\end{array}$ & 120 & 100 & Tinggi \\
\hline
\end{tabular}

Tabel 16. Rekapitulasi Total Skor, Indeks dan Interpretasi Hasil

\section{KESIMPULAN DAN SARAN}

\section{Kesimpulan}

Berdasarkan hasil penelitian dapat disimpulkan bahwa: Kerja sama yang terjadi antara transmigran dan penduduk asli terjalin begitu harmonis yang mana dalam kehidupan angka indeks interaksi sosial transmigran Desa Werdhi Agung dengan Penduduk asli di Kecamatan Dumoga Tengah berada pada titik $76,60 \%$ dan tergolong tinggi. Artinya kita lihat dalam masyarakat transmigrasi dan penduduk asli, yang mana dalam kehidupan keseharian mereka telah mencerminkan adanya suatu bentuk interaksi sosial yang baik terjadi di antara mereka yang belatar belakang etnis budaya yang berbeda, sehingga berdampak positif terhadap kehidupan sosial masyarakat transmigrasi dan penduduk asli yang hidup berdampingan. 
terhadap kehidupan sosial masyarakat transmigrasi dan penduduk asli yang hidup berdampingan, persaingan yang terjadi antara transmigran dan penduduk asli menunjukan bahwa dalam kehidupan bermasyarakat terdapat persaingan ditandai dengan adanya persaingan penguasaan tanah/lahan dan persaingan kecemburuan sosial antara pemuda-pemuda desa akan tetapi persaingan tersebut tidak sampai terjadi ancaman ataupun kekerasan, konflik yang terjadi antara transmigran dan penduduk asli menunjukan bahwa dalam suatu hubungan sosial maupun kehidupan sosial bermasyarakat tidak dapat dipungkiri bahwa konflik pasti ada, baik itu masih dalam keadaan stabil maupun sudah diluar batas. Adapun konflik yang terjadi antara transmigran dengan penduduk asli pada umumnya hanya terjadi pada penguasaan tanah/lahan, sedangkan konflik yang tidak sering terjadi ada pada konflik pemudapemuda desa namun tidak sampai menimbulkan perpecahan diantara transmigran dengan penduduk asli, akomodasi atau usaha-usaha mengakhiri pertikaian diantara pihak-pihak yang berkonflik antara transmigran dengan penduduk asli dapat diselesaikan dengan baik dengan cara kekeluargaan atau melibatkan pihak-pihak yang dianggap mampu mengatasi masalah yang ada dengan bantuan aparat desa maupun pemerintah.

\section{Saran}

Saran dalam penelitian ini yaitu kepada transmigran Desa Werdhi Agung dan penduduk asli di Kecamatan Dumoga Tengah untuk meningkatkan rasa solidaritas sosial agar tercipta kehidupan yang lebih baik. Menyarankan juga untuk menghilangkan rasa kecemburuan sosial atas kerja keras yang dilakukan oleh orang lain. Mengingat bahwa pentingnya hubungan antara kelompok masyarakat di Kecamatan Dumoga Tengah, maka diharapkan kepada seluruh masyarakat Dumoga khususnya masyarakat transmigrasi Desa Werdhi Agung dengan Penduduk asli untuk mempertahankan hubungan yang lebih baik.

\section{DAFTAR PUSTAKA}

Badan Pusat Statistik Sulawesi Utara. 2014. Sulut dalam Angka. 2014. Sulawesi Utara.

Fatnar, V.N., 2010. Kemampuan Interaksi Sosial Antara Remaja Yang Tinggal di Pondok Pesantren Dengan Yang Tinngal Bersama Keluarga. Jurnal. Fakultas Psikologi Universitas Ahmad Dahlan. Vol 2, No 1. (Diakses 10 November 2016)

Fitriani, Cicik., 2014. Interaksi Sosial Transmigran Jawa Dengan Masyarakat Lokal Di Desa Kayuagung Kecamatan Mepanga Kabupaten Parigi Moutung. Jurnal. Universitas Tadulako. Jawa. (Diakses 30 November 2016)

Gerungan, W. A., 2004. Psikologi Sosial. Jurnal. Bandung: PT Refika Aditama.

Halikin, 2014. Analisis Pola Interaksi Masyarakat Pendatang Terhadap Masyarakat Lokal Di Sumbawa Barat Studi Di Kecamatan Maluk Sumbawa Barat. Skripsi. Universitas Islam Negeri Syarif Hidayatullah. Jakarta (Diakses 6 Februari 2017)

Hereen, H. J., 1979. Transmigrasi di Indonesia. Jakarta: PT. Gramedia

Idianto, M, 2004. Interaksi Sosial Dalam Dinamika Sosial Budaya. Jakarta: Penerbit Erlangga.

Laiko, S, 1995. Taraf Hidup Petani Ditinjau Dari Pemanfaatan Pendapatan Keluarga di Daerah Transmigrasi Kecamatan Paguyuman Kabupaten Gorontalo.Skripsi.Fakultas Pertanian Universitas Samratulangi Manado.

Lawang, R,1985. Sistem Sosial Indonesia.Jakarta: Materi Kuliah Universitas Terbuka

Leibo, J, 1990. Sosiologi Pedesaan. Yogyakarta:Andi Offset.

Nasdian, F.T., 2015. Sosiologi Umum. Jakarta: Yayasan Pustaka Obor Indonesia.

Permana, R. C. E.,2011. Kearifan lokal tentang mitigasi bencana pada masyarakat Baduy.Artikel.Makara, Sosial Humaniora. 
Revida, E, 2006. Interaksi Sosial Masyarakat Etnik Cina dengan Pribumi di kota Medan Sumatera Utara. Jurnal Harmoni Sosial. Fakultas Fisip Universitas Sumatera Utara. Vol 1, No 1. ( Diakses 30 November 2016)

Riduwan, 2012. Pengantar Statistika Sosial. Bandung. Alfabeta

Soekanto, S, 1990. Sosiologi Suatu Pengantar. Jakarta: PT Raja Grafindo Persada.
Sugiharyanto, 2007. Migrasi Penduduk. Jakarta: Yudhistira Quadra.

Undang-undang Ketransmigrasian Nomor 15 Tahun 1997 Tentang Jenis-jenisTransmigrasi, 2009. Himpunan Peraturan Perundangundangan. Penerbit, Fokus Media, Bandung.

Walgito, B, 2003. Psikologi Sosial Suatu Pengantar. Yogyakarta: Andi Offset. 